\title{
The effect of genetically modified feeds on productivity, milk composition, serum metabolite profiles and transfer of tDNA into milk of cows
}

\author{
I. Furgał-Dierżuk' ${ }^{1}$, J. Strzetelski ${ }^{1}$, M. Twardowska ${ }^{3}$, K. Kwiatek $^{2}$ and M. Mazur ${ }^{2}$ \\ ${ }^{1}$ National Research Institute of Animal Production, Department of Animal Nutrition and Feed Science \\ 32-083 Balice, Poland \\ ${ }^{2}$ National Veterinary Research Institute, Department of Hygiene of Animal Feedingstuffs \\ al. Partyzantów 57, 24-100 Puławy, Poland \\ ${ }^{3}$ National Research Institute of Animal Production, National Laboratory for Feedingstuffs \\ Żubrów 1, 71-617 Szczecin, Poland
}

KEY WORDS: dairy cow milk, genetically modified maize and soyabean meal, tDNA transfer

Received: 14 May 2014

Revised: 4 March 2015

Accepted: 16 March 2015

${ }^{4}$ Corresponding author:

e-mail: iwona.furgal@izoo.krakow.pl

\begin{abstract}
The experiment was performed to determine whether transgenic maize containing the $B t$ gene (MON 810) and soyabean meal produced from glyphosate-tolerant plants (Roundup Ready, MON 40-3-2) compared with nontransgenic plants can affect the performance parameters, milk composition, blood serum metabolite profiles and transfer of tDNA into milk of cows. The experiment was carried out from the third week before parturition to the $305^{\text {th }}$ day of lactation on 40 Polish Holstein-Friesian cows, which were allotted to 4 groups of 10 animals according to body weight, milk yield and parity. The cows in all groups were fed a total mixed ration (TMR) formulated according to IZ-INRA (2009). The concentrate mixtures added to TMR contained: nonmodified (traditional) maize and soyabean meal (group $\mathrm{TM}_{\mathrm{G}} / \mathrm{TS}$ ); traditional maize and genetically modified (GM) soyabean meal (group TMG/MS); GM maize and traditional soyabean meal (group $\mathrm{MM}_{\mathrm{G}} / \mathrm{TS}$ ); or GM maize and GM soyabean meal (group $\mathrm{MM}_{\mathrm{G}} / \mathrm{MS}$ ). There were no significant differences between transgenic and non-transgenic feeds in productivity, milk composition and blood metabolite profiles such as: $\beta$-hydroxybutyric acid (BHBA), free fatty acids (FFA), glucose, insulin and progesterone. The transgenic DNA sequences of MON 810 and RR soyabean meal were not detectable by PCR in milk.
\end{abstract}

\section{Introduction}

The development and use of genetically modified (GM) crop biotechnology is considered an important tool to meet the feed requirements of livestock and the food demand of the human population (Sung et al., 2006), which will globally increase from the current 7 to 9 billion people in 2050. The demand for meat and milk will nearly double during this time, as described in a review by Flachowsky et al. (2013).

Genetically engineered crop plants can help eliminate the application of agricultural chemicals against different plant diseases. These crops have been genetically modified for a range of different traits, but herbicide tolerance and insect protection are the two most common traits, and maize and soyabeans are the most widely grown genetically modified crops. 
Over the last years the cultivated area of GM plants has rapidly increased around the world. In 2014, 181.5 million hectares of transgenic crops were grown globally, at an annual growth rate of $3 \%$ from 175.2 million hectares in 2013 (ISAAA, 2015).

In compound feeds for domestic animals, food production, and human nutrition, maize grain and soyabean meal are the most common and it is primarily these feeds that have been genetically modified.

The transgenic maize (MON 810) grown in Europe was modified by the integration of the crylAb gene (isolated from Bacillus thuringensis, $B t$ ), which encodes the insecticide Bt crystal protein, Cry1 Ab, that kills corn borer larvae, a major pest of maize in Europe.

The modified soyabean meal available on the Polish feed market is imported and derived from Roundup Ready (RR) genetically modified plants, which are produced by incorporating the epsps gene obtained from Agrobacterium sp. (strain CP4); in plants it expresses the enzyme 5-enolpyruvylshikimate-3-phosphate synthase, which assures resistance to the glyphosate herbicide, Roundup.

Genetically modified plants, as well as feeds and foods derived from them, have to undergo a risk assessment for animal and human health because of the possibility of horizontal gene transfer to feeds and animals producing food. At present in Poland there is an ongoing discussion whether to legally allow commercial GM crops (Lisowska and Cortez, 2013).

Cow's milk is one of the important foods in human nutrition due to its nutritional value and use as a raw material in processing into milk products.

There are few studies in Poland comparing the potential effects of $B t$ maize and glyphosate-tolerant (Roundup Ready) soyabean meal on productivity, milk composition and transfer of transgenic DNA into milk of cows.

Up to now most experiments with livestock were conducted to determine if fragments of transgenic DNA or their encoded protein were present in the digestive tract of livestock and in foods such as milk, meat and eggs (Flachowsky et al., 2012).

Studies on the detection of DNA in food products derived from animals receiving GM varieties modified for a single trait showed that GM crops can be considered equally safe for human health as those derived from animals fed conventional feeds (Flachowsky et al., 2005; Phipps et al., 2006; Einspanier, 2013). No significant differences were found in feed intake and milk production of crossbred dairy cows and the proteins encoded by 2 transgenes were not transferred to blood and milk in an experiment by Singhal et al. (2006). A study on Holstein dairy cows in a single reversal design indicated that silage modified with 2 transgenes (herbicide tolerance and insect resistance) also did not affect animal performance or milk composition, and no transgenic DNA or Cry1 Ab protein was detected in milk (Calsamiglia et al., 2007).

On the other hand, a study with goats showed that small DNA fragments can be detected not only in milk, but also in kid organs when mothers were fed GM soyabeans; it also revealed elevated levels of lactic dehydrogenase (LDH) in tissues, suggesting an increase in cell metabolism (Tudisco et al., 2010).

The long-term feeding trials on Simmental cows described by Guertler at al. (2010) showed that no recombinant DNA or Cry1 Ab protein was detected in milk, blood and urine, whereas the Cry $1 \mathrm{Ab}$ protein that could be found in the faeces and milk of cows fed genetically modified maize grain for 25 months should be classified as not different from the milk of cows fed non-transgenic maize. The later studies of Guertler at al. (2012) found that GM maize (MON810) compared with near-isogenic feed has no effect on major genes involved in apoptosis, inflammation and cell cycle in the gastrointestinal tract and in the liver of dairy cows.

There were no consistent effects of feeding maize grain MON810 or its isogenic line on milk yield and composition or body condition. A longterm study demonstrated the compositional and nutritional equivalence of MON810 and its isogenic counterpart line (Steinke et al., 2010).

In respect to plasma metabolic parameters of Simmental cows fed iso- and transgenic feeds in the first period of lactation, no clear differences were found in the concentration of most metabolites (Steinke at al., 2009).

The results of most transgenic feed experiments cited above were favourable but not always conclusive. For this reason, they were difficult to legislate and commercialize in some countries (including Poland) due to concerns over the health safety of feeds and foods for animals and humans.

Thus the experiment on Polish Holstein-Friesian cows under Polish feeding conditions was carried out.

The aim of the study was to evaluate the effect of transgenic maize grain (MON810) containing the $B t$ gene, genetically modified to protect itself against the European corn borer and soyabean meal produced from glyphosate-tolerant (Roundup Ready, MON 40-3-2) plants on productivity and milk composition, serum metabolite profiles and transfer of tDNA into milk. 


\section{Material and methods}

\section{Tested feeds}

The genetically modified maize grain $\left(\mathrm{MM}_{\mathrm{G}}\right)$ and modified soyabean meal (MS) were compared with non-modified feeds, here called traditional $\left(\mathrm{TM}_{\mathrm{G}}\right.$ and TS). The $\mathrm{TM}_{\mathrm{G}}$ and $\mathrm{MM}_{\mathrm{G}}$ was produced in Poland under similar conditions. The TS and MS was imported from Brazil by the company Agsol, Poland. The GM maize grain was obtained from plants containing the $B t$ gene and expressing the Cry1 Ab protein (Yield Gard, MON810), genetically modified for protection against the European corn borer (Ostrinia numbilatis). The tested soyabean meal was produced from glyphosate-tolerant plants (Roundup Ready, MON-40-3-2). The non-modified, isogenic parental line of maize grain (DKC 3420) and non-modified commercial soyabean meal served as control feeds.

\section{Experimental design and animal feeding}

The experiment was carried out on 40 Polish Holstein-Friesian cows arranged into 4 groups of 10 animals according to an analogue method based on parity (from 1 to 3 ), maximum milk yield of primiparous cows at the peak of lactation and of multiparous cows in the previous lactation and body weight (BW) three or four weeks before calving (mean: $604 \mathrm{~kg}$, range 477 to $692 \mathrm{~kg}$ ). The experiment was carried out until 305 days of lactation. The Local Kraków Ethics Committee for Experiments with Animals approved all of the experimental procedures relating to the use of live animals.

The cows were kept in a loose barn. Three or four weeks before predicted parturition the cows were moved to a calving pen where they stayed for 5 to 7 days after calving.

During lactation all of the cows were fed a total mixed ration (TMR), but before parturition (approximately the last 3 weeks), the TMR offered during lactation was diluted with 50\% straw barley chaff (length about $6 \mathrm{~cm}$ ). The composition of TMR (Table 1), the concentrate mixtures added to TMR (Table 2) and their feed value were calculated according to the IZ PIB-INRA (2009) recommendations, using INRAtion-PrévAlim version $3 \times(2005)$ software basing on our own chemical analysis.

The concentrate mixtures added to the TMR contained: non-modified, traditional maize grain and soyabean meal (group $\mathrm{TM}_{\mathrm{G}} / \mathrm{TS}$ ), traditional maize grain and modified soyabean meal (group $\mathrm{TM}_{\mathrm{G}} / \mathrm{MS}$ ), modified maize grain and traditional soyabean meal (group $\mathrm{MM}_{\mathrm{G}} / \mathrm{TS}$ ), or modified maize grain and soyabean meal (group $\mathrm{MM}_{\mathrm{G}} / \mathrm{MS}$ ).
Table 1. Total mixed ratio (TMR) composition for all groups ( $\%$ in dry matter (DM)) (depending on the group, the concentrates added to TMR consisted of: transgenic or/and non-transgenic maize grain and transgenic or/and non-transgenic soyabean meal)

\begin{tabular}{lr}
\hline Feeds & $\%$ \\
\hline Concentrate mixture & 35.0 \\
Grass silage & 7.0 \\
Maize silage & 45.0 \\
Lucerne-grass silage & 6.0 \\
Beet pulp silage & 6.0 \\
Rapeseed cake (9.6\% fat in DM) & 1.0 \\
\hline
\end{tabular}

Table 2. Composition of concentrates, as fed, $\%$

\begin{tabular}{|c|c|c|c|c|}
\hline \multirow{2}{*}{ Item } & \multicolumn{4}{|c|}{ Concentrates for groups } \\
\hline & $\mathrm{TM}_{\mathrm{G}} / \mathrm{TS}$ & $\mathrm{TM}_{\mathrm{G}} / \mathrm{MS}$ & $\mathrm{MM}_{\mathrm{G}} / \mathrm{TS}$ & $\mathrm{MM}_{\mathrm{G}} / \mathrm{MS}$ \\
\hline Maize MON810, ground & - & - & 51.5 & 51.5 \\
\hline Traditional maize, ground & 51.5 & 51.5 & - & - \\
\hline RR soyabean meal & - & 25.0 & - & 25.0 \\
\hline Traditional soyabean meal & 125.0 & - & 25.0 & - \\
\hline Barley, ground & 10.0 & 10.0 & 10.0 & 10.0 \\
\hline Triticale, ground bran & 5.0 & 5.0 & 5.0 & 5.0 \\
\hline Wheat, ground bran & 5.0 & 5.0 & 5.0 & 5.0 \\
\hline Limestone & 1.0 & 1.0 & 1.0 & 1.0 \\
\hline $\begin{array}{l}\text { Premix Blatin -TMR Mix } \\
\qquad(\mathrm{BASF})^{1}\end{array}$ & 2.5 & 2.5 & 2.5 & 2.5 \\
\hline
\end{tabular}

$\mathrm{TM}_{\mathrm{G}} / \mathrm{TS}$ - non-modified, traditional maize grain and traditional soyabean meal, $\mathrm{TM}_{\mathrm{G}} / \mathrm{MS}$ - traditional maize grain and modified soyabean meal, $\mathrm{MM}_{\mathrm{G}} / \mathrm{TS}$ - modified maize grain and traditional soyabean meal, $\mathrm{MM}_{\mathrm{G}} / \mathrm{MS}$ - modified maize grain and soyabean meal; RR - Roundup Ready; ${ }^{1}$ 93.1\% DM; $\mathrm{g} \cdot \mathrm{kg}^{-1}$ : P 30.0, Ca 180.0, Mg 100.0, Na 80.0; $\mathrm{mg} \cdot \mathrm{kg}^{-1}$ DM: Cu 1200, Zn 8700, Mn 4040, Co 17.0, Se 40.0, I 83.0; IU $\cdot \mathrm{kg}^{-1} \mathrm{DM}$ : vit. A 1000000 , vit. D 80000 , vit. E 2500

The cows were fed in groups and the TMR ration was given according to the average daily milk yield of the cows in the feeding group. Rations were formulated taking into account the average body weight of the cows in each group about six months before calving and assuming that after calving the maximum milk production at the peak of lactation should reach $35 \mathrm{~kg}$ per day. When the mean milk yields of cows in groups decreased to $28 \mathrm{~kg}$ per day and then to $18 \mathrm{~kg}$ per day, the daily rations of TMR were changed. The TMR was formulated using a fodder wagon $\left(10 \mathrm{~m}^{3}\right)$ and the physical form of TMR was checked by Pen State Particle Separator (PSPS) screens. The refusals from each feeding group were weighed for groups during lactation on one day every two weeks before the morning feeding.

In addition, effective rumen degradability (ERD) of dry matter $\left(\mathrm{ERD}_{\mathrm{DM}}\right)$ and crude protein $\left(\mathrm{ERD}_{\mathrm{CP}}\right)$ in the traditional (non-modified) and genetically modified maize grain (MON810) and RR soyabean meal were determined on three permanently fistulated dry cows with a mean body weight of $680 \mathrm{~kg}$ employing the in sacco method according to Polish standards (Kowalski et al., 2008). The samples were 
incubated for 2, 4, 8, 16, 24 and $48 \mathrm{~h}$ after feeding. The basic daily ration for fistulated cows consisted of, kg: meadow hay 6 and concentrate mixture 2.56 , containing, $\%$ : barley 44 , wheat bran 40 , soyabean meal 12, vitamin-mineral premix 3 and ground limestone 1 . The ration was formulated to meet maintenance requirements (about $0.5 \mathrm{~kg}$ milk per day) and three weeks before incubation of feed samples the basic ration for cows was offered.

\section{Sampling}

Samples of each feed were taken three times for analysis. Representative samples of refusals were analysed three times from three days: days 33, 47, 61; days 75, 89, 100; and days 150, 200, 250 .

The curves of changes in the body weight of the cows in lactation were developed taking into account the measurements on days: from 5-7 after calving, every two weeks thereafter and from 100 days lactation.

Milk yield was estimated daily using Milk Master equipment. Milk composition was determined in representative daily samples collected from each cow every two weeks throughout lactation, starting from \pm 10 days after calving. The samples were refrigerated at $4{ }^{\circ} \mathrm{C}$ for no longer than 2 weeks.

On days 120, 150 and 220 after calving, a total of 72 milk samples were collected from 6 cows from each group and analysed for suspected presence or absence of the transgenic DNA of genetically modified RR soyabean and $B t$ maize (MON 810). The collected milk samples were frozen at $-20^{\circ} \mathrm{C}$ and stored until DNA analysis.

Starting from the first week after calving to 4 weeks of lactation, blood samples were taken on days $7,10,17$ and 24 from the jugular vein about $4 \mathrm{~h}$ after the morning feeding and blood serum was preserved at $-20^{\circ} \mathrm{C}$ until analysis.

\section{Analysis}

The chemical composition of feeds and representative samples of refusals were analysed according to AOAC (2005) methods. The volatile fatty acids (VFA) in silages (protein requirement and energy value calculated) were analysed by gas chromatography using a Varian 3400 apparatus and $8200 \mathrm{CX}$ autosampler, and a CP-Wax 58 capillary column $(25 \mathrm{~m} \times 53 \mu \mathrm{m} \times 1 \mu \mathrm{m})$. The initial furnace temperature of the column $\left(80^{\circ} \mathrm{C}\right)$ was increased by $7^{\circ} \mathrm{C} \cdot \mathrm{min}^{-1}$ until $270^{\circ} \mathrm{C}$. The injection temperature was $200^{\circ} \mathrm{C}$ and the detector temperature, $260^{\circ} \mathrm{C}$. Helium was used as the carrier gas at a flow of $6 \mathrm{ml} \cdot \mathrm{min}^{-1}$. One millilitre of water extract from the silages was applied to the column. Silage $\mathrm{pH}$ was determined with the Auto Kjeldahl Unit K-370 (Bischi) using the $\mathrm{pH}$ determination function. Lactic acid was determined by high performance liquid chromatography (HPLC) after separation of water permeates with $24 \%$ met-phosphoric acid using a Lichrocart Superspher RP $18250 \mathrm{~cm}$ column, UV detector at $210 \mathrm{~nm}$, fluent $\left(1 \mu 1 \mathrm{H}_{2} \mathrm{O}+100 \mu \mathrm{H}_{2} \mathrm{SO}_{4}\right.$, $\left.1 \mathrm{ml} \cdot \min ^{-1}\right)$, and injection $20 \mu 1$.

The milk composition was determined using a Milko-Scan FT 120 (Foss Electric, Denmark).

Free fatty acids (FFA) in blood serum were determined colorimetrically using acyl-CoA synthetase, oxidase, and peroxidase (WAKO Reagents). D-3 hydroxybutyric acid (BHBA) was determined by a kinetic enzymatic reaction using a Cobas-Bio analyser (Roche) and a high-sensitivity reagent kit (RANDOX). Glucose was determined using a VITROS 950 analyser (Ortho-Clinical Diagnostic; Test Methodology Manual. 1997). Progesterone was determined by a radioimmunology reaction (BioSource INS-IRMA Kit and BioSource PROG-RIA-CT Kits).

Polymerase chain reactions (PCR) were performed according to JRC (Joint Research Centre) GMO methods ("GMO METHODS: The European Union Database of Reference Methods for GMO Analysis"; gmo-crl.jrc.ec.europa.eu/gmomethods). The list of the primers used in the study, together with information relating to their base sequences $\left(5^{\prime}-3^{\prime}\right)$, target element and amplicon size, is given in Table 3.

PCR analysis was performed to determine the presence of transgenic DNA of GM soyabean meal and GM maize grain in concentrates and milk. DNA was extracted from concentrate and milk samples using CTAB methods (PN-EN ISO/IEC 21571:2007).

When effective rumen degradability was determined, the presence of transgenic DNA from GM feeds in samples after each hour of incubation was also estimated by PCR.

PCR analysis was also used to assess transfer of transgenic DNA of GM maize and soyabean meal into the rumen population of microorganisms. The rumen digesta were collected from 3 ruminally fistulated cows twice at a one-month interval, $6 \mathrm{~h}$ after feeding. Cows were fed for two weeks in the same manner as during the in sacco determination of ERD. DNA from each sample was isolated immediately after collection using a "Plasmid Mini" kit (A \& A Biotechnology cat. 020-250) to isolate plasmid DNA specific only for microorganisms and frozen at $-20^{\circ} \mathrm{C}$.

The results were subjected to one-way analysis of variance using the GLM procedure of SAS (2001). 
Table 3. Primers used in the study for the detection of maize and soyabean genes

\begin{tabular}{|c|c|c|c|c|}
\hline Primer & Sequence $5^{\prime}-3^{\prime}$ & Target element & $\begin{array}{l}\text { Amplicon size, } \\
\text { bp }\end{array}$ & References \\
\hline $\begin{array}{l}\text { 35s-f2 } \\
\text { Petu-r1 }\end{array}$ & $\begin{array}{l}\text { TGA TGT GAT ATC TCC ACT GAC G } \\
\text { TGT ATC CCT TGA GCC ATG TTG T }\end{array}$ & $\begin{array}{l}\text { Transition site of } 35 S \text { promoter sequence } \\
\text { to the chloroplast-transit-signal sequence } \\
\text { in Roundup Ready soyabean }\end{array}$ & 172 & QL-CON 00-001 \\
\hline $\begin{array}{l}\text { VW01 } \\
\text { VW03 }\end{array}$ & $\begin{array}{l}\text { TCG AAG GAC GAA GGA CTC TAA CG } \\
\text { TCC ATC TTT GGG ACC ACT GTC G }\end{array}$ & $\begin{array}{l}\text { Transition site of the genomic DNA into } \\
\text { the } 35 \text { S promoter in MON810 maize }\end{array}$ & 170 & QL-EVE-ZM 001 \\
\hline $\begin{array}{l}\text { p35s-cf3 } \\
\text { p35s-cf4 }\end{array}$ & $\begin{array}{l}\text { CCA CGT CTT CAAAGC AAG TGG } \\
\text { TCC TCT CCAAAT GAAATG AAC TTC C }\end{array}$ & $\begin{array}{l}\text { CaMV 35s promoter of RR soyabean } \\
\text { and MON810 maize }\end{array}$ & 123 & QL-ELE-00-004 \\
\hline $\begin{array}{l}\text { HA-NOS 118-f } \\
\text { HA-NOS 118-r }\end{array}$ & $\begin{array}{l}\text { GCA TGA CGT TAT TTA TGA GAT GGG } \\
\text { GAC ACC GCG CGC GAT AAT TTA TCC }\end{array}$ & NOS terminator of RR soyabean & 118 & QL-ELE 00-009 \\
\hline $\begin{array}{l}\text { GM03 } \\
\text { GM04 }\end{array}$ & $\begin{array}{l}\text { GCC CTC TAC TCC ACC CCC ATC C } \\
\text { GCC CAT CTG CAA GCC TTT TTG TG }\end{array}$ & Soyabean lectin gene (endogenous) & 118 & QL-CON 00-001 \\
\hline $\begin{array}{l}\text { IVR1-F } \\
\text { IVR1-R }\end{array}$ & $\begin{array}{l}\text { CCG CTG TAT CAC AAG GGG TGG TAC C } \\
\text { GGA GCC CGT GTA GAG CAT GAC GAT }\end{array}$ & Maize invertase gene (endogenous) & 226 & QL-EVE-ZM 001 \\
\hline
\end{tabular}

The differences between treatments were then estimated using the LSM - least square mean method. $P<0.05$ was considered significant.

The curves showing changes in daily milk yield in subsequent days of lactation, depending on treatments, were calculated using Quick Statistica (1992), according to the equation:

$$
\mathrm{Y}=\mathrm{a} \log \mathrm{x}+\mathrm{bx}+\mathrm{c}
$$

where: $\mathrm{Y}$ and $\mathrm{x}$ - mean daily yield and lactation day, respectively.

\section{Results}

\section{Tested feed}

The composition and nutritional value of $B t$ maize and RR soyabean meal compared with commercial, isogenic traditional lines did not differ from the standard range and the feed value of the four concentrates added to TMR contained, on average, similar levels of protein and energy (Table 4).

Nutritive value of TMR for all groups was similar and levels of protein and energy (per $\mathrm{kg} \mathrm{DM}$ ) averaged: $167.5 \pm 8.5 \mathrm{~g}$ CP, $99.5 \pm 2.0 \mathrm{~g}$ PDIN, $91 \pm 2.5 \mathrm{~g}$ PDIE and $0.96 \pm 0.01$ UFL (Table 5).

\section{Dry matter and protein digestibility in the rumen}

The average effective degraded dry matter in the rumen $\left(\mathrm{ERD}_{\mathrm{DM}}\right)$ was similar (Table 6) for genetically modified and non-modified maize grain, but effective degraded crude protein $\left(\mathrm{ERD}_{\mathrm{CP}}\right)$ of genetically modified maize grain was somewhat higher than for $\mathrm{TM}_{\mathrm{G}}$. ERD $\mathrm{DM}_{\mathrm{D}}$ and $\mathrm{ERD}_{\mathrm{CP}}$ of GM soyabean meal were slightly greater compared with traditional feed.

During $48 \mathrm{~h}$ of incubation (for each hour) we did not find any statistically significant differences $(P>0.05)$ between percentage values (Figure 1) of

Table 4. Nutritive value of maize grain and soyabean meal (transgenic or non-transgenic) and concentrates (in kg DM), according to IZ-PIB INRA (2009)

\begin{tabular}{|c|c|c|c|c|c|c|c|c|}
\hline Feeds & $\begin{array}{l}\text { Dry } \\
\text { matter } \\
\mathrm{g}\end{array}$ & $\begin{array}{l}\text { Crude } \\
\text { protein } \\
\mathrm{g}\end{array}$ & $\begin{array}{l}\text { Ether } \\
\text { extract } \\
\mathrm{g}\end{array}$ & $\begin{array}{l}\text { Crude } \\
\text { fiber } \\
\mathrm{g}\end{array}$ & Ash & $\begin{array}{l}\text { PDIN } \\
\mathrm{g}\end{array}$ & $\begin{array}{l}\text { PDIE } \\
\mathrm{g}\end{array}$ & UFL \\
\hline Traditional maize, ground & 862 & 89 & 41.1 & 22.1 & 15.3 & 70 & 95 & 1.21 \\
\hline Maize MON810, ground & 863 & 89 & 39.8 & 21.3 & 14.7 & 70 & 95 & 1.21 \\
\hline Traditional soyabean meal & 878 & 554 & 29.5 & 39.8 & 63.6 & 404 & 276 & 1.24 \\
\hline RR soyabean meal & 887 & 515 & 36.6 & 48.7 & 71.2 & 376 & 260 & 1.25 \\
\hline \multicolumn{9}{|l|}{ Concentrates for groups } \\
\hline $\mathrm{TM}_{\mathrm{G}} / \mathrm{TS}^{1}$ & 872 & 210 & 39 & 41 & 39 & 154 & 138 & 1.16 \\
\hline $\mathrm{TM}_{\mathrm{G}} / \mathrm{MS}^{1}$ & 874 & 201 & 35 & 37 & 39 & 155 & 138 & 1.16 \\
\hline $\mathrm{MM}_{G} / \mathrm{TS}^{1}$ & 872 & 211 & 40 & 43 & 38 & 155 & 138 & 1.16 \\
\hline $\mathrm{MM}_{\mathrm{G}} / \mathrm{MS}^{1}$ & 874 & 201 & 35 & 40 & 38 & 148 & 134 & 1.16 \\
\hline
\end{tabular}

${ }^{1}$ see Table 2; PDIN - protein digestible in the intestine corresponds to the amount of microbial protein synthesised in the rumen which depends on level of nitrogen originating from protein in the rumen plus dietary protein undegraded; PDIE - protein digestible in the intestine corresponds to the amount of microbial protein synthesised in the rumen which depends on energy available plus dietary protein undegraded; PDI - total protein digestibility in the intestine meeting the requirement of animal which corresponds to lower value of PDIN or PDIE; UFL - feed unit for milk production, $1 \mathrm{UFL}=1.7 \mathrm{Mcal}$ 
Table 5. Chemical composition, nutritive value and fermentation product (FP) of TMR in groups (in kg DM) according to IZ-PIB INRA (2009)

\begin{tabular}{|c|c|c|c|c|c|c|c|c|c|}
\hline Groups $^{1}$ & $\begin{array}{l}\text { Dry } \\
\text { matter \% }\end{array}$ & $\begin{array}{l}\text { Crude } \\
\text { protein, } \mathrm{g}\end{array}$ & $\begin{array}{l}\text { Ether } \\
\text { extract, } g\end{array}$ & $\begin{array}{l}\text { Crude } \\
\text { fibre, } g\end{array}$ & $\begin{array}{l}\text { Ash } \\
g\end{array}$ & $\begin{array}{l}\text { PDIN }^{2} \\
\mathrm{~g}\end{array}$ & $\begin{array}{l}\mathrm{PDIE}^{2} \\
\mathrm{~g}\end{array}$ & $\mathrm{UFL}^{2}$ & $\begin{array}{l}\mathrm{FP}^{3} \\
\mathrm{~g}\end{array}$ \\
\hline $\mathrm{TM}_{\mathrm{G}} / \mathrm{TS}$ & 42.9 & 159 & 30 & 163 & 75 & 98 & 91 & 0.97 & 38 \\
\hline $\mathrm{TM}_{\mathrm{G}} / \mathrm{MS}$ & 41.1 & 163 & 30 & 168 & 80 & 100 & 91 & 0.96 & 39 \\
\hline $\mathrm{MM}_{\mathrm{G}} / \mathrm{TS}$ & 43.4 & 159 & 30 & 161 & 74 & 98 & 91 & 0.97 & 39 \\
\hline $\mathrm{MM}_{G} / \mathrm{MS}$ & 41.1 & 165 & 30 & 178 & 88 & 102 & 91 & 0.94 & 34 \\
\hline
\end{tabular}

${ }^{1}$ see Table $2 ;{ }^{2}$ see Table $4 ;{ }^{3} \mathrm{FP}=$ acetic acid + propionic acid + butyric acid + lactic acid

Table 6. Effective rumen degradability of dry matter $\left(E R D_{D M}\right)$ and crude protein $\left(E R D_{C P}\right)$ in of traditional and modified maize grain and soyabean meal $(\mathrm{k}=0.06 \%)^{1}$

\begin{tabular}{lll}
\hline Item & $\mathrm{ERD}_{\mathrm{DM}}$ & $\mathrm{ERD}_{\mathrm{CP}}$ \\
\hline Maize MON810, ground & 58.0 & 44.0 \\
Traditional maize, ground & 58.1 & 41.3 \\
RR soyabean meal & 67.6 & 59.0 \\
Traditional soyabean meal & 70.1 & 62.6 \\
\hline
\end{tabular}

$\mathrm{k}$ - the rumen outflow rate taken as $0.06(\% / \mathrm{h}) ;{ }^{1}$ were calculated using NEWAY EXEL (Chen,1995)

dry matter and crude protein degradability of both maize grain types. The differences in rumen degradation of crude protein GM soyabean meal were statistically significant $(P=0.02)$ only for the $4-h$ incubation.
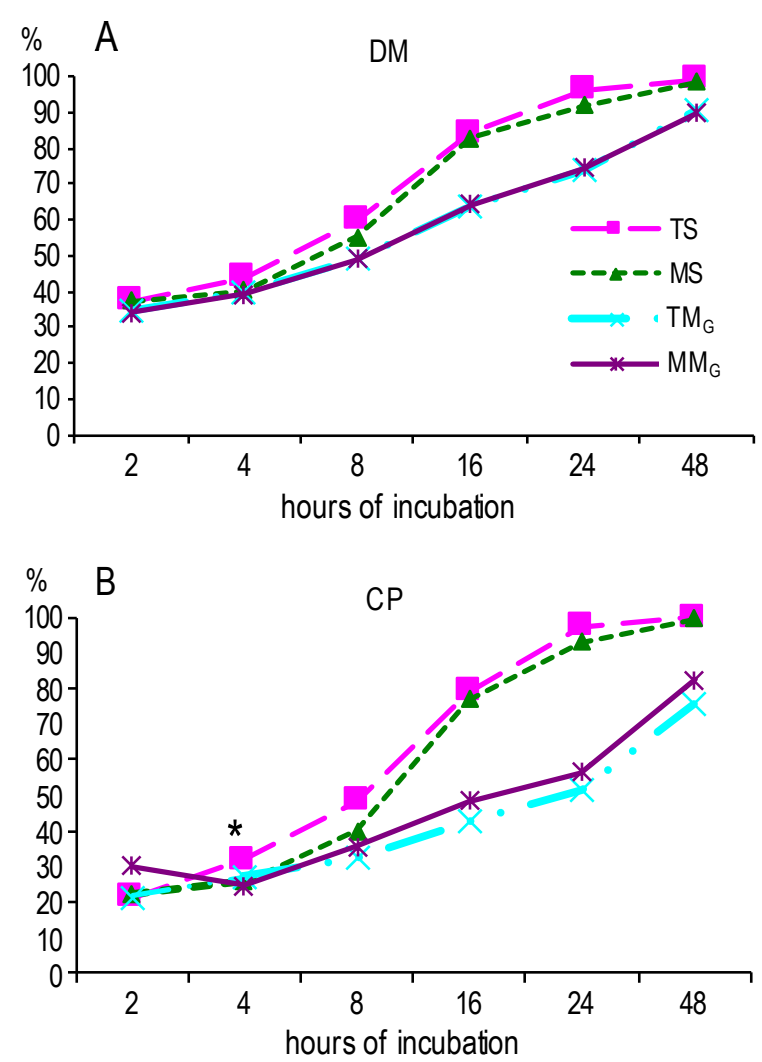

Figure 1. Changes of rumen degradability of dry matter $(A)$ and crude protein; (B) during incubation $\mathrm{TM}_{G}$ - traditional maize grain, $\mathrm{MM}_{G}$ - genetically modified maize grain (MON810), TS - traditional soyabean meal, MS - genetically modified soyabean meal (Roundup Ready); ${ }^{*} P=0.02$

\section{Production, milk composition, and body weight}

Intake of TMR and nutrients during the experiment period was comparable in all experimental groups (Table 7).

There was no effect $(P>0.05)$ of diets on milk production or milk composition (Table 8 ), whereas statistically significant differences $(P<0.01)$ were found for the lactation period, which was shorter in the control group $\left(\mathrm{TM}_{\mathrm{G}} / \mathrm{TS}\right)$.

The course of lactation curves indicates that the milk production of cows in particular groups was similar during all lactation periods (Figure 2).

The efficiency of diet and nutrient utilization per kilogram milk production of the average cow in a group was similar in all of the groups (Table 9).

Table 7. Intake of Total mixed ration and nutrients (average for cow in group per day)

\begin{tabular}{lllllll}
\hline Groups $^{1}$ & $\begin{array}{l}\text { Dry } \\
\text { matter } \\
\%\end{array}$ & $\begin{array}{l}\text { Crude } \\
\text { protein } \\
\mathrm{g}\end{array}$ & $\begin{array}{l}\mathrm{PDIN}^{2} \\
\mathrm{~g}\end{array}$ & $\begin{array}{l}\mathrm{PDIE}^{2} \\
\mathrm{~g}\end{array}$ & $\begin{array}{l}\mathrm{PDIP}^{2} \\
\mathrm{~g}\end{array}$ & $\mathrm{UFL}^{2}$ \\
\hline $\mathrm{TM}_{\mathrm{G}} / \mathrm{TS}$ & 19.4 & 3085 & 1882 & 1765 & 660 & 18.82 \\
$\mathrm{TM}_{\mathrm{G}} \mathrm{IMS}$ & 18.7 & 3048 & 1870 & 1702 & 654 & 17.95 \\
$\mathrm{MM}_{\mathrm{G}} / \mathrm{TS}$ & 19.4 & 3085 & 1901 & 1765 & 679 & 18.82 \\
$\mathrm{MM}_{\mathrm{G}} / \mathrm{MS}$ & 18.8 & 3102 & 1918 & 1711 & 677 & 17.61 \\
\hline${ }^{1}$ see Table 2; &
\end{tabular}

Table 8. Total and daily milk production and milk composition

\begin{tabular}{|c|c|c|c|c|c|c|}
\hline \multirow{2}{*}{ Item } & \multicolumn{4}{|l|}{ Groups ${ }^{1}$} & \multirow{2}{*}{$P$} & \multirow{2}{*}{ SE } \\
\hline & $\mathrm{TM}_{\mathrm{G}} / \mathrm{TS}$ & $\mathrm{TM}_{\mathrm{G}} / \mathrm{MS}$ & $\mathrm{MM}_{\mathrm{G}} / \mathrm{TS} \mathrm{I}$ & $\mathrm{MM}_{G} / \mathrm{MS}$ & & \\
\hline $\begin{array}{l}\text { Total milk yield, } \\
\mathrm{kg} / \mathrm{cow}\end{array}$ & 7900 & 7998 & 8043 & 8079 & 0.99 & 206. \\
\hline $\begin{array}{l}\text { Daily milk yield, } \\
\text { kg/day/cow }\end{array}$ & 27.69 & 26.66 & 2690 & 27.52 & 0.94 & 4 \\
\hline $\begin{array}{l}\text { Period of lactation, } \\
\text { days }\end{array}$ & $285.3^{a}$ & $300.0^{\mathrm{b}}$ & $299.0^{b}$ & $293.3^{\mathrm{ab}}<$ & $<0.01$ & 1 \\
\hline \multicolumn{7}{|l|}{ Milk composition, \% } \\
\hline dry matter, \% & 12.58 & 12.28 & 12.95 & 12.48 & 0.07 & 0.09 \\
\hline fat, & 3.78 & 3.55 & 3.48 & 3.94 & 0.24 & 0.0 \\
\hline pro & 3.23 & 3.24 & 3.19 & 3.29 & 0.38 & 0.02 \\
\hline lactose, $\%$ & 4.74 & 4.81 & 4.80 & 4.77 & 0.70 & 0.02 \\
\hline urea, $\mathrm{mg} \cdot \mathrm{I}^{-1}$ & 203 & 183 & 190 & 212 & 0.55 & 7.44 \\
\hline casein, $\%$ & 2.59 & 2.60 & 2.74 & 2.58 & 0.08 & 0.03 \\
\hline fat/protein & 1.17 & 1.10 & 1.10 & 1.19 & 0.39 & 0.0 \\
\hline
\end{tabular}

${ }^{1}$ see Table 2; ab means with different superscipts within a row are significantly different at $\mathrm{P} \leq 0.05$ 


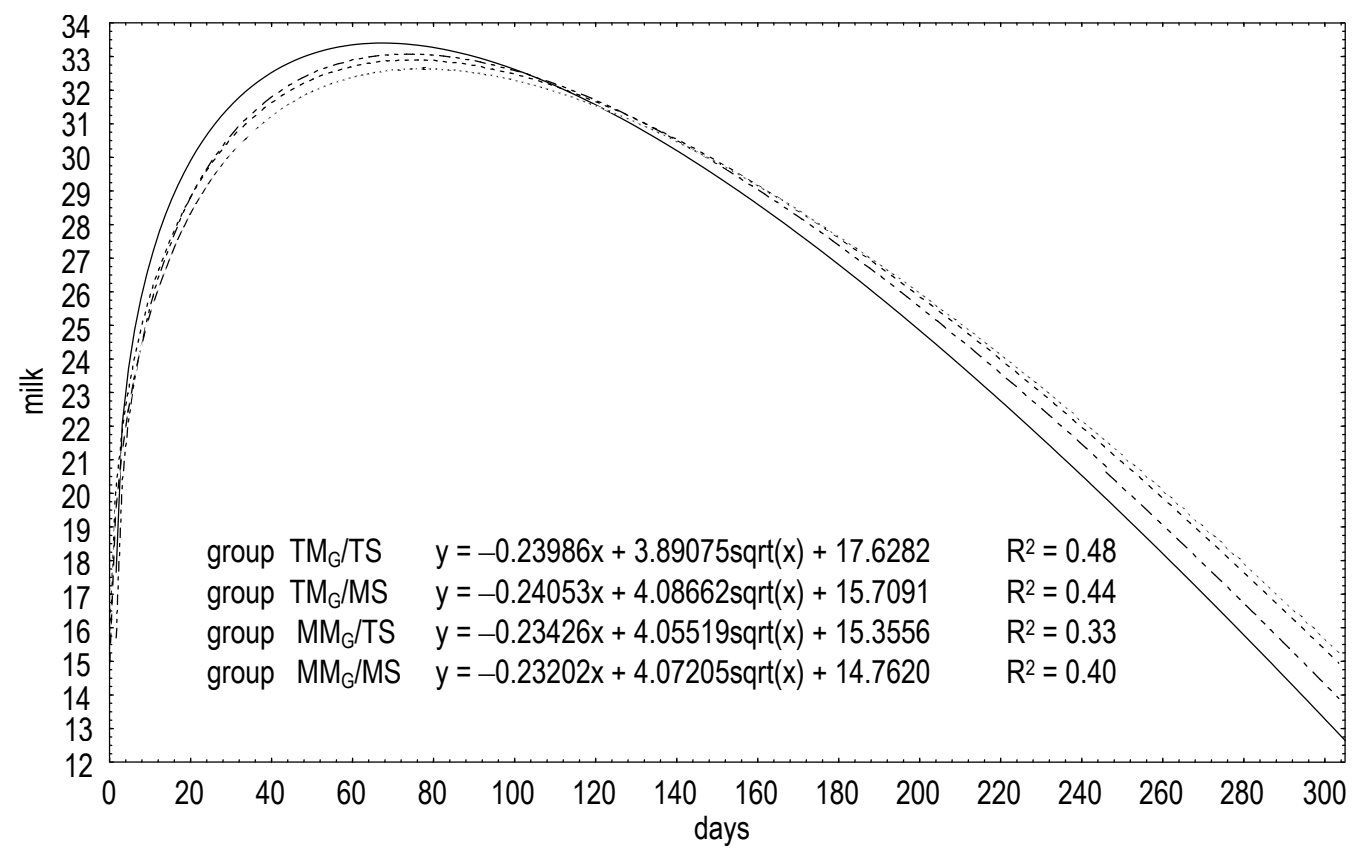

Figure 2. Changes in daily milk yield during lactation, $\mathrm{kg} \cdot \mathrm{d}^{-1} ; \mathrm{TM}_{\mathrm{G}} / \mathrm{TS}$ - non-modified, traditional maize grain and traditional soyabean meal, $\mathrm{TM}_{\mathrm{G}} / \mathrm{MS}$ - traditional maize grain and modified soyabean meal, $\mathrm{MM}_{\mathrm{G}} / \mathrm{TS}$ - modified maize grain and traditional soyabean meal, $\mathrm{MM}_{G} / \mathrm{MS}^{-}$modified maize grain and soyabean meal

Table 9. Feed and nutrient conversion per kg milk of average cow in group

\begin{tabular}{|c|c|c|c|c|c|}
\hline Groups ${ }^{1}$ & $\begin{array}{l}\text { Dry } \\
\text { matter, } \\
\mathrm{kg}\end{array}$ & $\begin{array}{l}\text { Crude } \\
\text { protein, } \\
\mathrm{g}\end{array}$ & $\begin{array}{l}\mathrm{PDI}^{2} \\
\mathrm{~g}\end{array}$ & $\mathrm{UFL}^{2}$ & $\begin{array}{l}\text { Concentrates, } \\
\mathrm{kg}\end{array}$ \\
\hline$\overline{\mathrm{TM}_{\mathrm{G}} / \mathrm{TS}}$ & 0.70 & 111.41 & 63.74 & 0.67 & 0.25 \\
\hline $\mathrm{TM}_{\mathrm{G}} / \mathrm{MS}$ & 0.70 & 114.32 & 63.84 & 0.67 & 0.25 \\
\hline $\mathrm{MM}_{\mathrm{G}} / \mathrm{TS}$ & 0.70 & 114.68 & 65.61 & 0.70 & 0.26 \\
\hline $\mathrm{MM}_{G} / \mathrm{MS}$ & 0.70 & 112.72 & 62.17 & 0.64 & 0.25 \\
\hline
\end{tabular}

${ }^{1}$ see Table 2; ${ }^{2}$ see Table 4

No statistically significant differences were noted between the groups for each measurement day. The final average body weight (ABW) was higher than the initial ABW. The increase in average body weight during lactation for particular cow groups ranged between $41 \mathrm{~kg}$ in group $\mathrm{MM}_{\mathrm{G}} / \mathrm{TS}$ to $81 \mathrm{~kg}$ in group $\mathrm{TM}_{\mathrm{G}} / \mathrm{TS}$ (Figure 3).

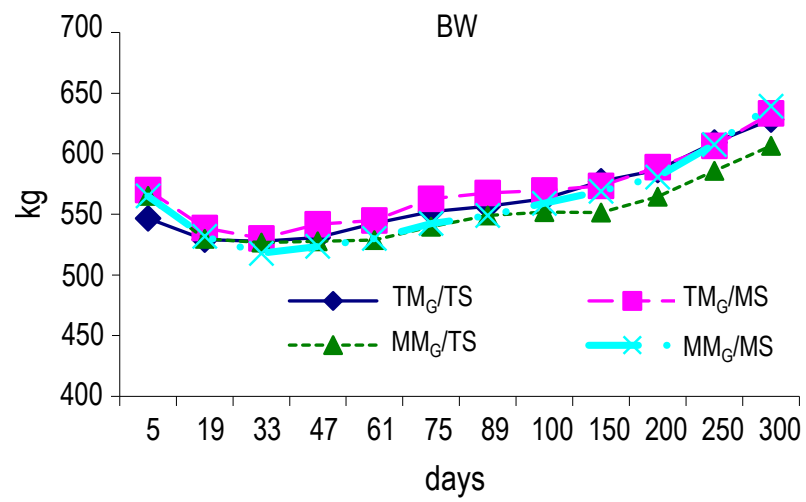

Figure 3. Changes in body weight (BW) during lactation; $\mathrm{TM}_{\mathrm{G}} / \mathrm{TS}$, $\mathrm{TM}_{\mathrm{G}} / \mathrm{MS}, \mathrm{MM}_{\mathrm{G}} / \mathrm{TS}, \mathrm{MM}_{\mathrm{G}} / \mathrm{MS}$ - see Figure 2

\section{Blood serum metabolite profiles}

Regarding the metabolic parameters in blood serum, no statistically significant differences $(P>0.05)$ in serum concentrations of FFA or BHBA were noted between the averages for groups on each measurement day (Figure 4), although on day 7 after
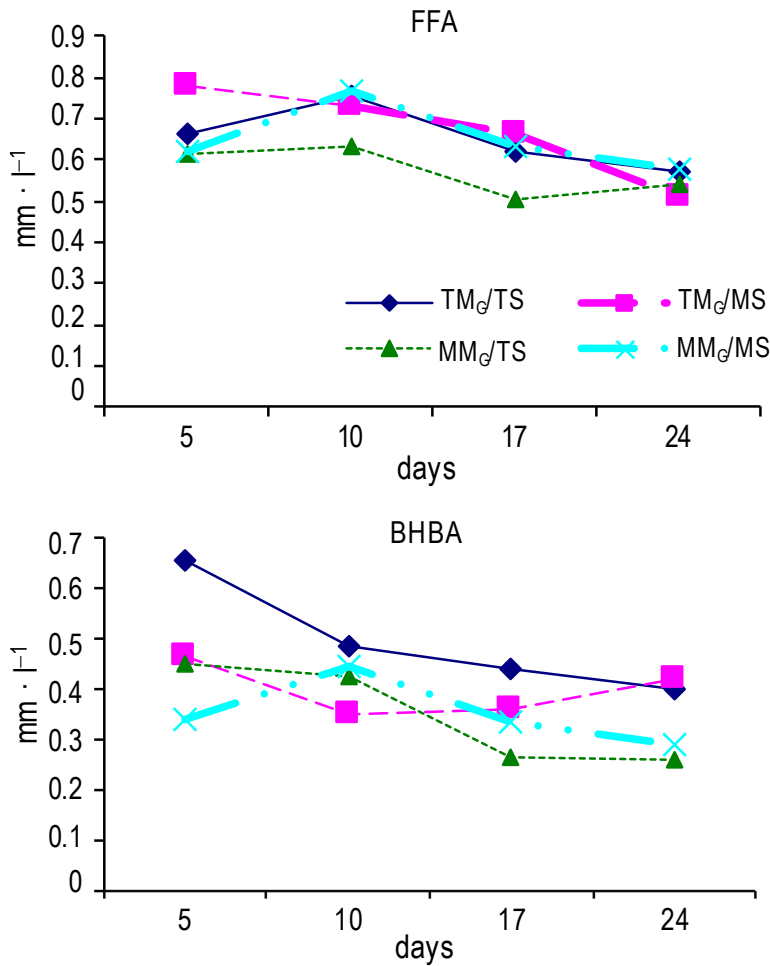

Figure 4. Concentration of free fatty acids (FFA) and $\beta$-hydroxybutyric acid (BHBA) in blood serum; $\mathrm{TM}_{G} / \mathrm{TS}, \mathrm{TM}_{G} / \mathrm{MS}, \mathrm{MM}_{\mathrm{G}} / \mathrm{TS}, \mathrm{MM}_{\mathrm{G}} / \mathrm{MS}$ - see Figure 2 

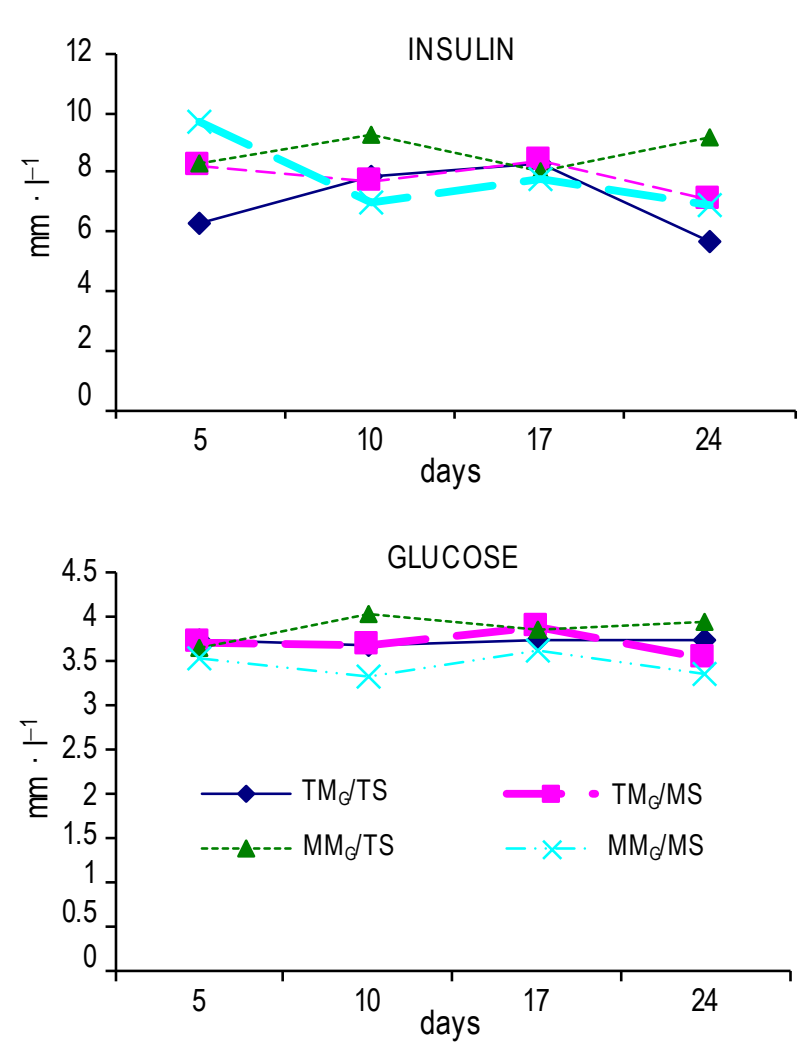

Figure 5. Concentration of insulin and glucose in blood serum; $\mathrm{TM}_{\mathrm{G}} / \mathrm{TS}, \mathrm{TM}_{\mathrm{G}} / \mathrm{MS}, \mathrm{MM}_{\mathrm{G}} / \mathrm{TS}, \mathrm{MM}_{\mathrm{G}} / \mathrm{MS}$ - see Figure 2

calving a tendency towards higher (group $\mathrm{TM}_{\mathrm{G}} / \mathrm{TS}$ ) and lower (group $\mathrm{MM}_{\mathrm{G}} / \mathrm{MS}$ ) BHBA concentrations was observed $(P<0.09)$.

Also no significant differences were found among the groups in insulin and glucose concentrations for almost each study period, except for the glucose concentration (Figure 5) on day 10 after calving. On this day it was lower in group $\mathrm{MM}_{\mathrm{G}} \mathrm{MS}$, in which cows received genetically modified maize grain MON 810 and RR soyabean meal $(P<0.04)$.

The mean concentrations of blood metabolic parameters among groups of dairy cows were not statistically different, although there was a tendency towards a higher glucose concentration in group

Table 10. Average concentration of blood metabolic parameters

\begin{tabular}{|c|c|c|c|c|c|c|}
\hline \multirow{2}{*}{ Groups $^{1}$} & \multicolumn{4}{|c|}{ During 4 weeks after calving, mean } & \multicolumn{2}{|c|}{$\begin{array}{l}\text { Progesterone, } \\
\mathrm{ng} \cdot \mathrm{m}^{-1}\end{array}$} \\
\hline & $\begin{array}{l}\mathrm{FFA} \\
\mathrm{mm} \cdot \mathrm{I}^{-1}\end{array}$ & $\begin{array}{l}\mathrm{BHBA} \\
\mathrm{mm} \cdot \mathrm{l}^{-1}\end{array}$ & $\begin{array}{l}\text { insulin, } \\
\mu U \cdot F^{-1}\end{array}$ & $\begin{array}{l}\text { glucose } \\
\mathrm{mm} \cdot \mathrm{I}^{-1}\end{array}$ & $\begin{array}{l}\text { day } 14 \\
\text { of lactation }\end{array}$ & $\begin{array}{l}\text { day } 21 \\
\text { n of lactation }\end{array}$ \\
\hline $\mathrm{TM}_{\mathrm{G}} / \mathrm{TS}$ & 0.66 & 0.49 & 7.28 & 3.73 & 0.48 & 0.51 \\
\hline $\mathrm{TM}_{\mathrm{G}} / \mathrm{MS}$ & 0.68 & 0.39 & 7.76 & 3.71 & 0.51 & 0.57 \\
\hline $\mathrm{MM}_{\mathrm{G}} / \mathrm{TS}$ & 0.58 & 0.35 & 8.88 & 3.99 & 0.57 & 0.62 \\
\hline $\mathrm{MM}_{\mathrm{G}} / \mathrm{MS}$ & 0.66 & 0.37 & 8.27 & 3.62 & 0.57 & 0.58 \\
\hline$P$ & 0.45 & 0.12 & 0.40 & 0.08 & 0.09 & 0.44 \\
\hline SE & 0.02 & 0.02 & 0.34 & 0.05 & 0.02 & 0.02 \\
\hline
\end{tabular}

${ }^{1}$ see Table 2; FFA - free fatty acids; BHBA - $\beta$-hydroxybutyric acid in blood serum
Table 11. Content of genetically modified plants in concentrates

\begin{tabular}{|c|c|c|c|c|}
\hline \multirow[b]{2}{*}{ Modification } & \multicolumn{4}{|c|}{ Concentrates for groups $^{1}$} \\
\hline & $\overline{\mathrm{TM}_{\mathrm{G}} / \mathrm{TS}}$ & $\mathrm{TM}_{\mathrm{G}} / \mathrm{MS}$ & $\mathrm{MM}_{\mathrm{G}} / \mathrm{TS}$ & $\mathrm{MM}_{\mathrm{G}} / \mathrm{MS}$ \\
\hline RR soyabean meal', $\%$ & 0.05 & 100 & 0.23 & 82 \\
\hline Maize grain MON 810, \% & 0.01 & 0.05 & 27.6 & 24.6 \\
\hline
\end{tabular}

$\mathrm{MM}_{\mathrm{G}} / \mathrm{TS}(P<0.08)$ and progesterone concentration on day 14 of lactation in group $\mathrm{MM}_{\mathrm{G}} / \mathrm{MS}(P<0.09)$.

\section{Results of DNA analysis}

Analysis of compound feed samples showed that the concentrate given to groups $\mathrm{TM}_{\mathrm{G}} / \mathrm{TS}$ and $\mathrm{MM}_{\mathrm{G}} / \mathrm{TS}$ contained very low levels of GM soyabean meal, while the concentrate for groups $\mathrm{TM}_{\mathrm{G}} / \mathrm{MS}$ and $\mathrm{MM}_{\mathrm{G}} \mathrm{MS}$ contained $100 \%$ and $82 \%$ GM soyabean meal, respectively (Table 11). The content of GM maize MON810 in the concentrate for groups $\mathrm{TM}_{\mathrm{G}}$ ' TS and $\mathrm{TM}_{\mathrm{G}} / \mathrm{MS}$ points to trace amounts of GM maize grain MON810 in the concentrate for groups $\mathrm{MM}_{\mathrm{G}} / \mathrm{TS}$ and $\mathrm{MM}_{\mathrm{G}} / \mathrm{MS}(27.6 \%$ and $24.6 \%$, respectively).

There was no horizontal transfer of DNA originating from GM feeds into plasmid DNA of microorganisms existing in the rumen of cows fed the concentrate for group $\mathrm{MM}_{\mathrm{G}} / \mathrm{MS}$.

Transgenic DNA fragments from insect-resistant maize (MON 810) and herbicide-tolerant soyabean (Roundup Ready) were not detected in any of the cow milk samples.

The feed samples of Roundup Ready soyabean meal collected from all three cows after 2 and 4 $h$ of incubation in the rumen were contaminated with transgenic DNA. Transgenic DNA in samples of $B t$ maize grain (MON 810), collected from 3 cows after $2 \mathrm{~h}$ of incubation in the rumen was observed in three cows, and after $4 \mathrm{~h}$ of incubation in one cow. Transgenic DNA of both GM feeds was not found in any of the samples after $8 \mathrm{~h}$ of rumen incubation.

\section{Discussion}

The chemical composition and feed value of GM maize and soyabean meal used in the present study were not modified in relation to traditional soyabean and maize grain. Although numerically small differences were observed in feed values, they were within the normal expected range and were comparable to the feeds used in Poland (Table 4). Some studies show that the composition of commercial glyphosate-tolerant soyabeans, compared over three years with multiple varieties remains equiva- 
lent to that of non-modified conventional soyabeans (McCann et al., 2005). Beever et al. (2003) showed that transgenic feedstuffs had similar feeding values to isogenic feeds and did not adversely affected animal performance. Phipps et al. (2003), who fed cows a total mixed ration (TMR) containing either maize silage from a genetically modified (GM) variety, which was tolerant to the herbicide glufosinate ammonium, or its near isogenic no-GM counterpart, reported similar composition and nutritive values of both feeds.

Rossi et al. (2005), who compared Bt maize grain with the corresponding near isogenic line in feeding broilers, reported some numerical differences in chemical composition, but the variability of nutrient contents was not different between both forms of maize grain. The results of the many animal experiments already completed have mostly revealed no significant differences between isogenic and transgenic hybrids (Flachowsky et al., 2005). Results confirming the absence of significant differences between $B t$ maize grain MON 810 and glyphosate-tolerant soyabean meal in relation to traditionally non-modified components in feeding calves were reported by Furgał-Dierżuk et al. (2014). GM plants of the first generation used in the present study are characterized as being without substantial changes in composition and nutritive value and can be generally considered equivalent to their isogenic counterpart (Flachowsky et al., 2013).

McCann et al. (2005) reported that the composition of soyabean seeds and processed fractions genetically modified for glyphosate tolerance (event 40-3-2 and 61-67-1) were comparable to the nonmodified seeds and fractions of conventional soyabean meal.

The average values of $\mathrm{ERD}_{\mathrm{DM}}$ and $\mathrm{ERD}_{\mathrm{CP}}$ of traditional and genetically modified maize $\left(\mathrm{TM}_{\mathrm{G}}\right.$ and $\mathrm{MM}_{\mathrm{G}}$ ) and soyabean meal (TS and MS) showed the lack of distinct differences in effective rumen degradation of dry matter and crude protein (Table 6, Figure 1). These results and average percentage values of dry matter and crude protein degradability suggest that GM feeds should not influence feed value. However, the somewhat higher curve of crude protein $B t$ maize grain degradability during incubation and lower RR soyabean meal compared with conventional feeds, suggest small changes in protein structure. In an in vitro study Sung et al. (2006) used a diet with rice straw and maize (MON810/ Event176/DK729) and found no significant differences in digestibility of dry matter, NDF, or ADF at 12 and $24 \mathrm{~h}$ in the rumen for both transgenic and isogenic forms of maize. Using an in situ technique,
Wiedeman et al. (2006) showed (as in our experiment) that ruminal digestion decreased the presence of functional cry $1 \mathrm{Ab}$ gene fragments and that it was unlikely that full-size functional Cry $1 \mathrm{Ab}$ protein molecules would be present after $8 \mathrm{~h}$ incubation in the rumen. In our experiment, after 8-h rumen incubation of $B t$ maize grain and RR soyabean meal, we observed no evidence of the presence of tDNA specific for $B t$ maize and RR soyabean meal within the detection limits.

The effect of genetically modified $B t$ maize grain and RR soyabean meal on productivity, milk composition, DM intake of cows, and nutrient conversion in the present study (Tables: 7, 8, 9 and Figure 2) was in agreement with earlier studies. Grant et al. (2003) found no differences in feed intake, milk production, milk composition, and milk component yields between cows fed $B t$ maize and non- $B t$ near-isogenic hybrids. However, in our experiment a tendency appeared between groups towards a different content of dry matter $(P=0.07)$ and casein $(P=0.08)$ in milk and differences in lactation periods were observed $(P<0.01)$. Steinke et al. (2010), who studied the effect of feeding $B t$ maize (MON810) to Simmental cows, showed no significant differences between GM feed and near isogenic control, although the milk of cows fed $B t$ maize had a significantly higher content of fat, lactose and protein. The authors suggest that the differences in milk composition between isogenic- and transgenic-fed dairy cows were not due to the different kind of feed, but rather to individual or physiological differences between the animals. In a study by Calsamiglia et al. (2007), feeding 2GM maize silage to lactating Holstein cows did not affect DM intake or milk yield, but increases were observed in the content of milk protein, lactose, and SNF. The absence of differences between treatments in the body weight of cows during lactation (Figure 3) may suggest that in all groups the diets similarly and sufficiently covered the requirements of the cow and foetus.

The absence of differences between treatments found in the present experiment in terms of the FFA, BHBA and progesterone concentrations in blood serum (Figure 4, Table 10) suggest that transgenic feed compared with isogenic lines did not negatively affect the health and reproductive status of the cows. Trabalza-Marinucci et al. (2008) showed that a diet including insect-resistant $B t 176$ maize did not have adverse effects on the health of ewes over a three-year period. The lack of statistically significant differences between treatments in the concentration of glucose (with the exception of the sample from day 10) and insulin in blood serum (Figure 5) 
suggests the similar energetic status of cows in all groups, as also indicated by the serum concentrations of FFA and BHBA. It can be assumed that the cows in all groups were at a similar risk of fatty liver and similarly prone to ketosis. The higher $(P=0.04)$ glucose concentration in the sample collected on day 10 of lactation from cows in the $\mathrm{MM}_{\mathrm{G}} / \mathrm{TS}$ group could have resulted from a different physiological and metabolic status of the experimental animals and/or feed intake on that day. Steinke et al. (2009), who fed dairy cows $B t$ maize in two consecutive lactations, found the serum glucose concentration to be higher $(P<0.05)$ in transgenic-fed cows over the first lactation of the trial.

The content of GM plants in the experimental concentrates suggests that the compound feeds had the appropriate composition (Table 11). The percentage of GM plants in concentrates containing their isogenic counterpart $(0.04 \%-0.5 \%)$ shows that non-modified soyabean meal and maize grain were conventional lines without RR soyabean and maize MON 810 (Table 11). Generally, a $0.9 \%$ content of GM plants is acceptable in isogenic crop plants. In the context of evaluating GM in plants, such a level is admissible if the detection of the GM component was accidental.

In the present study, in the experimental feeding groups no milk sample was suspected to contain tDNA specific for $B t$ maize and RR soyabean meal within detection limits. These results are in accordance with previous findings that also reported the absence of recombinant DNA and protein in milk cows (Phipps et al., 2003; Nemeth et al., 2004; Calsamiglia, et al., 2007; Guertler et al., 2009; Einspanier, 2013) and in milk goats (Rizzi et al., 2008), although chloroplast DNA fragments were detected in milk. Degradation of the intact transgenic DNA and protein during feed processing and storage, and during ruminal and intestinal digestion might be the reasons for the absence of these recombinant fragments in milk. After feed intake, both the DNA and protein are further degraded within the bovine gastrointestinal tract (Lutz et al., 2006; Wiedemann et al., 2006). Paul et al. (2010) reported that the Cry $1 \mathrm{Ab}$ protein from MON810 is increasingly degraded during digestion in the dairy cow gastrointestinal tract via small fragments, and in comparison with total protein in feed, the relative amount of CrylAb protein in faeces is markedly reduced, indicating that CrylAb protein is not more stable than other proteins in the feed.

In contrast to those results, Tudisco et al. (2007, 2010, 2015) showed that small DNA fragments can be detected in milk goats fed soyabean meal. Agodi et al. (2006) detected small fragments of recombinant DNA in analysed milk samples from the Italian market, which they suspected was due to feed and faecal contamination during milking of cows fed genetically modified diets. In a study by Guertler et al. (2010), the CrylAb protein was found in faeces, whereas no recombinant DNA or Cry1Ab protein was detected in milk.

Absence of horizontal gene transfer to ruminal microorganisms was found not only in our study, but also by other researchers. Trabalza-Marinucci et al. (2008), who fed ewes a diet with $B t$ maize, found no differences compared with isogenic feed for total amylolytic and cellulolytic bacterial concentrations, as well as protozoa numbers and composition. Sung et al. (2006), when comparing the effects of transgenic maize (MON 810 and Event176) and isogenic maize (DK729) on in vitro rumen fermentation showed that bacterial population numbers were not affected by transgenic corn.

Feed DNA fragments may be transferred into the tissue, milk and eggs of animals as a natural process. When finally reviewing all available data, there is no scientific evidence that milk, meat, or eggs derived from animals fed feed containing commercialized GM-plants are less safe for the consumer than those produced with conventional feed (Einsapanier, 2013).

\section{Conclusions}

The indicators of milk yield and composition, as well as dry matter intake, body weight and blood serum metabolite profile of cows obtained in this study support the conclusion that a total mixed ration with insect-resistant MON810 maize and glyphosatetolerant soyabean meal (Roundup Ready) did not affect production parameters or the health of cows. The chemical composition of the feeds, as well as the rumen dry and crude protein degradability of genetically modified feed remain substantially equivalent to conventional feeds. Transgenic DNA fragments from genetically modified Roundup Ready soyabean meal and $B t$ maize were not detected in milk by PCR methods and did not influence the rumen microorganism population. The current results conform to earlier work with plants of the "first generation", e.g., without substantial changes. There is, however, a need for new, quality studies using new/ other plants, e.g. bio-fortified plants or plants with substantial changes in composition, and new, more sensitive, analytical methods. 


\section{References}

Agodi A., Barchitta M., Grillo A., Sciacca S., 2006. Detection of genetically modified DNA sequences in milk from the Italian market. Int. J. Hyg. Environ.-Health 209, 81-88

AOAC, 2005. Association of Official Analytical Chemists. Official Methods of Analysis. $18^{\text {th }}$ Edition. Arlington. VA

Beever D.E., Phipps R.H., 2001. The fate of plant DNA and novel proteins in feeds for farm livestock: a United Kingdom perspective. J. Anim. Sci. 79, E290-E295

Calsamiglia S., Hernandez B., Hartnell G.F., Phipps R., 2007. Effects of corn silage derived from a genetically modified variety containing two transgenes on feed intake, milk production, and composition, and the absence of detectable transgenic deoxyribonucleic acid in milk in Holstein dairy cows. J. Dairy Sci. 90, 4718-4723

Chen X.B., 1995. Neway Excel: An Excel Application Program for Processing Feed Degradability Data. International Feed Resources Unit, Rowett Research Institute

Einspanier R., 2013. The fate of transgenic DNA and newly expressed proteins. In: G. Flachowsky (Editor). Animal Nutrition with Transgenic Plants. CAB International. Wallingford, OX (UK), pp. 130-139

Flachowsky G. (Editor), 2013. Animal Nutrition with Transgenic Plants. CAB International Series, Vol 1, 234 Wallingford, OX (UK)

Flachowsky G.A., Chesson A., Aulrich K., 2005. Animal nutrition with feeds from genetically modified plants. Arch. Anim. Nutr. 59 $1-40$

Flachowsky G.A., Schafft H., Meyer U., 2012. Animal feeding studies for nutritional and safety assessments of feeds from genetically modified plants: a review. J. Verbr. Lebensm. 7, 179-194

Furgał-Dierżuk I., Strzetelski J., Kwiatek K., Twardowska M., Mazur M., Sieradzki Z., Kozaczyński W., Reichert M., 2014. The effect of genetically modified maize (MON 810) and soybean meal (Roundup Ready) on rearing performance and transfer of transgenic DNA to calf tissues. J. Anim. Sci. 23, 13-22

Grant R.J., Fanning K.C., Kleinschmit D., Stanisiewski E.P., Hartnell G.F., 2003. Influence of glyphosate-tolerant (event nk603) and corn root worm protected (event MON863) corn silage and grain on feed consumption and milk production in $\mathrm{Hol}-$ stein cattle. J. Dairy Sci. 86, 1707-1715

Guertler P., Vijay P., Albrecht Ch., Meyer H.D., 2009. Sensitive and highly specific quantitative real-time PCR and ELISA for recording a potential transfer of novel DNA and Cry1 Ab protein from feed into bovine milk. Anal. Bioanal. Chem. 393, 1629-1638

Guertler P., Paul V., Steinke K., Wiedemann S., Preißinger W., Albrecht C., Spiekers H., Schwarz F.J., Meyer H.H.D., 2010. Long-term feeding of genetically modified corn (MON810)_fate of cry $1 \mathrm{Ab}$ DNA and recombinant protein during the metabolism of the dairy cow. Livest. Sci. 131, 250-259

Guertler P., Brandl Ch., Meyer H.H.D. Tichopad A., 2012. Feeding genetically modified maize (MON810) to dairy cows: comparison of gene expression pattern of markers for apoptosis, inflammation and cell cycle. J. Verbr. Lebensm. 7 , 195-202

ISAAA, 2015. Global status of commercialised transgenic crops: 2014 ISAAA, Ithaca, New York

IZ PIB-INRA, 2009. Standards for ruminant feeding (in Polish). National Research Institute of Animal Production, Kraków

Kowalski Z.M., Strzetelski J.A., Niwińska B., Nowak W., Pajak J., Szyszkowska A., 2008. Standard methods for determination of feed protein degradation in the digestive tract of ruminants (in Polish). Wiad. Zoot. R. XLVI, 4, 53-58
Lisowska K., Cortez A., 2013. Health risk assessment of genetically modified crops in domestic studies - a literature review (in Polish). J.Ecol. Health 17, 26-32

Lutz B., Wiedemann S., Albrecht C., 2006. Degradation of transgenic Cry1 $\mathrm{Ab}$ DNA and protein in Bt-176 maize during the ensiling process. J. Anim. Physiol. Anim. Nutr. (Berl.) 90,116-123

McCann M.C., Liu K., Trujillo W.A., Dobert C.D., 2005. Glyphosatetolerant soybeans remain compositionally equivalent to conventional soybeans (Glycine max L.) during three years of field testing. J. Agric. Food Chem. 53, 5331-5335

Nemeth A., Wurz A., Artim L., Charlton S., Dana G., Glenn K., Hunst P., Jennings J., Shilito R., Song P., 2004. Sensitive PCR analysis of animal tissue samples for fragments of endogenous and transgenic plant DNA. J. Agr. Food Chem. 52, 6129-6135

Quick Statistica, 1992. Statistical Analyses System ver. 5.1

Paul V., Guertler P., Wiedemann S., Meyer H.H., 2010. Degradation of Cry1Ab protein from genetically modified maize (MON810) in relation to total dietary feed proteins in dairy cow digestion. Transgenic Res. 19, 683-689

Phipps R.H., Deaville E.R., Maddison B.C., 2003. Detection of transgenic DNA and endogenous plant DNA in rumen fluid, duodenal digesta, milk, blood and feces of lactating dairy cows. J. Dairy. Sci. 86, 4070-4078

Phipps R.H., Einspanier R., Faust M.A., Chesson A., Flachowsky G., Nutti M.R., Price W.D., 2006. Safety of meat, milk, and eggs from animals fed crops derived from modern biotechnology. Animal Agriculture's Future through Biotechnology. Issue Paper 34, Part 5. Council for Agricultural Science and Technology (CAST), Ames, lowa

Rizzi A., Brusetti L., Arioli S., Nielsen K.M., Tamagnini I., Tamburini A., Sorlini C., Daffonchio D., 2008. Detection of feed-derived maize DNA in goat milk and evaluation of the potential of horizontal transfer to bacteria. Eur. Food Res. Technol. 227, 1699-1709

Rossi F., Morlacchini M., Fusconi G., Pietri A., Mazza R., Piva G., 2005. Effect of $B t$ corn on broiler growth performance and fate of feed-derived DNA in the digestive tract. Poultry Sci. 84. 1022-1030

SAS., 2001. Release 2.6 for Windows. SAS Institute INC. SAS Campus Drive Cary. NC

Singhal K.K., Tyagi A.K., Rajput Y.S., Singh M., Perez T., Hartnell G.F., 2006. Effect of feeding cottonseed produced from Bollgard II cotton on feed intake, milk production, and milk composition in lactating crossbred cows. In: Proceedings of The $12^{\text {th }}$ Animal Science Congress of the Asian-Australian Association of Animal Production Societies (AAAP), pp. 757 (Abstr.) Busan (South Korea)

Steinke K., Paul V., Guertler P., Preißinger W., Wiedemann S., Albrecht C., Spiekers H., Meyer H.H., Schwarz F.J., 2009. Effects of long-term feeding of genetically modified maize (Bt-maize; MON810) to dairy cows on performance and metabolic parameters. Proc. Soc. Nutr. Physiol.18

Steinke K., Guertler P., Paul V., Wiedemann S., Ettle T., Albrecht C., Meyer H.H., Spiekers H., Schwarz F.J., 2010. Effects of longterm feeding of genetically modified corn (event MON810) on the performance of lactating dairy cows. J. Anim. Physiol. Anim. Nutr. (Berl) 94(5), e185-e193

Sung H.G., Min D.M., Kim D.K., Li D.Y., Kim H.J., Upadhaya S.D., Ha J.K., 2006. Influence of transgenic corn on the in vitro rumen microbial fermentation. Asian-Aust. J. Anim. Sci. 19, (12), $1761-1768$

Trabalza-Marinucci M., Brandi G., Rondini C. et al., 2008. A three-year longitudinal study on the effects of a diet containing genetically modified Bt176 maize on the health status and performance of sheep. Livestock Sci. 113, 178-190 
Tudisco R., Calabro S., Cutrignelli M.I., Mopniello G., Grossi M., Mastellone V., Lombardi B., Pero M., Infascelli F., 2015. Genetically modified soybean in a goat diet: Influence on kid performance. Small Ruminant Res. http://dx.doi.org/10.1016/j. smallrumies.205.01.023

Tudisco R., Cutrignelli M.I., Calabro S., Cuglielmelli A., Infascelli F. 2007. Investigation on genetically modified soybean (Roundup Ready) in goat nutrition: DNA detection in suckling kids. Ital. J. Anim. Sci. 6, Suppl.1, 380-382
Tudisco R., Mastellone V., Cutrignelli M.I., Lombardi P., Bovera F., Mirabella N., Piccolo G., Calabro S., Avallone L., Infascelli F., 2010. Fate of transgenic DNA and evaluation of metabolic effects in goats fed genetically modified soybean and in their offsprings. Animal 4, 1662-1671

Wiedemann S., Lutz B., Kurtz H., Schwarz F.J., Albrecht C., 2006. In situ studies on the time-dependent degradation of recombinant corn DNA and protein in the bovine rumen. J. Anim. Sci. $84,135-144$ 